\title{
Wenzhou Family Enterprise Ownership Structure and Optimization Strategy
}

\author{
Haihuai He \\ Wenzhou Vocational \& Technical College, Zhejiang, China, 325035 \\ 374183657@qq.com
}

\begin{abstract}
Keywords: Wenzhou, Family enterprise, Ownership structure, Optimize.
Abstract: Based on the analysis of the survey of management structure and efficiency of Wenzhou family business, found that the ownership structure of Wenzhou family business have the characteristic of family member control the majority of the stocks, keep increasing capital, ownership structure getting more complex, human capital and intangible assets do not get valued. Based on the in-depth analysis of the ownership structure of corporate governance mechanisms influence, points out that Wenzhou family business externalize some equity, Separated family business ownership and management by the agency, encourage transferring Wenzhou family business part of stock listed, attract institutional investors to achieve diversification and dynamic ownership structure, and then make Wenzhou family enterprises Ownership Structure better.
\end{abstract}

\section{Introduction}

Because of Wenzhou family business along the path of "household responsibility system and domestic work $\rightarrow$ operations $\rightarrow$ partnership or joint-stock cooperative $\rightarrow$ limited liability companies". No matter what form of business, it has a strong influence by a family. Generally speaking, family business is that the ownership and management of enterprises owned by a family. From this point of view, almost all of small and medium-sized enterprises in Wenzhou is family businesses. So the study of Wenzhou family business ownership structure has typical sense.

Unique ownership structure and management structure of family business are the source of vitality of the family business and limited further development. First, ownership is highly concentrated in family members, and the ownership structure is relatively stable; Secondly, the Board of Directors decision reflects the will of the family business; third, the enterprise agency has a strong personal relationship with color, it contains a lot of emotional and ethical factors. In order to save transaction costs, reduce system cost and improve system efficiency, family businesses will promote the improvement and Change management structure, looking for a new family business management structure for the modern economy. We selected 100 family business that have more than three years of history as a sample enterprise survey, a total of 96 valid questionnaires, by 96 Wenzhou Family Business Survey, can analyze basic Wenzhou Family Enterprise Governance Structure Ownership Structure situation.

\section{Characteristics of Wenzhou Family Company Ownership Structure}

\subsection{Ownership is highly concentrated in family members}

Wenzhou family business family shareholders "dominance" is really common. The family holds the absolute controlling. Family enterprises are monopoly-controlled management structure model, and its main feature is that the company's equity is highly concentrated. Most of the business starts by an 
individual or a couple, the main majority of enterprise are based on a family, which leads to the family business ownership is highly concentrated in the hands of the founder and his family.

Venture capital and development capital of Wenzhou family business, basically are self-sufficient. Not only venture capital is essentially raised by the owners or family, but also development capital are basically rely on their self-accumulation. Compared with the starting period of the family business, the currently funding of family business is changed, but the main channel is still out of the income and borrowing from relatives and friends, the main source of investment is owners and their family members.

Table1. Wenzhou Family Business investment sources Distribution

\begin{tabular}{ccc}
\hline Investor & Number of Enterprise & Percentage $(\%)$ \\
\hline Owner & 96 & 100 \\
\hline Family member & 77 & 80.2 \\
\hline Other Individuals & 49 & 51.0 \\
\hline Other Company & 10 & 10.4 \\
\hline Other Country & 5 & 5.2 \\
\hline Do not Declare & 19 & 19.8 \\
\hline
\end{tabular}

\subsection{Family members’ investment make enterprises gradually expanded capital}

Owners and family members of Wenzhou family business have majority of the stock. According to the survey, owners and family members of the co-owned enterprises accounted for the total equity to $100 \%$ have the proportion of $33.3 \%, 19.8 \%$ have $90 \%-100 \%$ of stock, $16.7 \%$ have $80 \%-90 \%$ of stock, $10.4 \%$ have 70 to 80 percent of stock, $13.5 \%$ have $60 \%-70 \%$ of stock, $6.3 \%$ have $50 \%-60 \%$ of stock. Owners have ownership of enterprises for $100 \%$ of the equity have proportion of $19.8 \%, 18.8 \%$ have $90 \%-100 \%$ of stock, $8.3 \%$ have $80 \%-90 \%$ of stock, $8.3 \%$ have $70 \%-80 \%$ of stock, $24.0 \%$ have $60 \%$ $70 \%$ of stock , $6.3 \%$ have $50 \%-60 \%$ of stock, and only $4.1 \%$ of owners have less than $50 \%$ of stock.

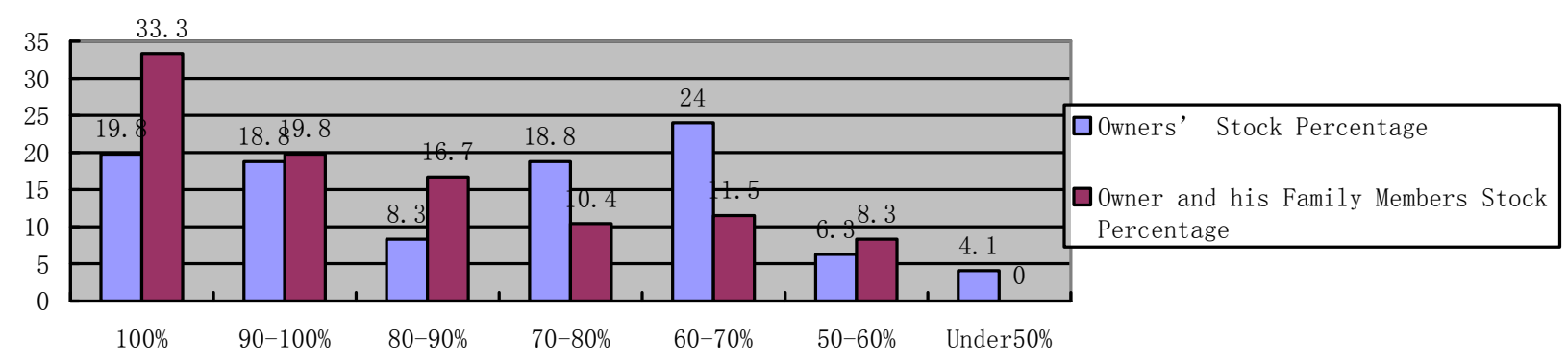

Fig.1. the distribution of the proportion of equity owners and family comparison

\subsection{Increasingly complex of ownership structure}

With the development of family businesses, family members' equity tend to go external dispersion, for example transferred stock to the operator or staff will help to improve the management structure of family business. One the one hand, improve employee motivation and loyalty to the company. On the other hand, when the company is listed or issuing stock to raise funds again, family members owned shares will be diluted. Family Business Ownership Structure over its development is getting complicated, especially listed companies. Family businesses often through the backdoor listing by family members to achieve control of listed companies indirectly controlled by the way, which resulted in the family enterprise cross-shareholdings, which is difficult to have a clear ownership structure. 


\subsection{Do not view human capital equity and intangible equity important}

Wenzhou family businesses generally pay attention to physical assets, human capital is often ignored. Human capital cannot be reflected in the way of equity, resulting in the family business have lower ability to attract and stabilize staff. Meanwhile, family business with patented technology is the representative of intangible assets equity. Intangible assets investor have difficult to obtain long-term interests through equity, resulting in the family business have poor technology for updates, and most of them can only become production and processing enterprises.

\section{Ownership structure affects the corporate management mechanism}

From a historical and logical view of management structure, the ownership structure is the foundation of management structure, but also determines the operating performance. There is a close relationship between the three. Therefore, the optimal business performance to meet the family ownership structure must be the most conducive to play the role of management. These management mechanisms include incentive management, mergers and acquisitions, proxy contests and monitoring mechanisms.

\subsection{Ownership Structure and Incentive}

Ownership structure affects the company's management structure. The first performance of equity focus in favor of the company's business is incentives. Chairman of family business founded in the vast majority of business entrepreneurs. Because these entrepreneurs is the direct representative of the controlling shareholder of the family, he (she) interests as the interests of managers with those of shareholders is highly consistent. Operators active participation of the highest corporate governance and ownership structure in the other two, so that dispersed ownership interests of operators is difficult to be consistent with the interests of shareholders, minority shareholders to participate in the costs and benefits of corporate governance asymmetry. Even family relative holding but also because the proportion of shares is not great, active participation decline of corporate governance, the company's management incentive becomes more complicated.

According to the survey, $80.4 \%$ of the general managers are the main investor, which by the owners as a $50 \%$ by family members as $24 \%$ by other investors as accounted for $10.4 \%$, while served by the professional managers for $15.6 \%$. So, the identity of family business decision-making and management rights, the main investor and the main managers of the two are combined height were tested.

\subsection{Ownership Structure and proxy contest}

The presence or manager market manager replacement pressure is an important reason prompting managers to work hard. In the family shareholders "dominance" situation, which cannot be delegated agent defeat in the fight for the right agent with others in the process, which is not conducive to replace the manager. When ownership is highly fragmented manager in the corporate governance structure becomes more prominent position. Because of asymmetric information, their opinions and views can easily affect no opportunity to participate in company's minority shareholders. The motives of these shareholders hitchhike lack overthrow current manager or chairman of the initiative. In this case, proxy contests unlikely. Stoke in moderate concentration, and there under the ownership structure of several large shareholders, may be the most beneficial to the proxy contest, because the big shareholders have the ability and motivation to found problem in the managers' business decision-making. 


\subsection{Ownership Structure and oversight mechanisms}

Effective and direct supervision of the operators from the shareholders, and shareholders' equity structure for supervision is essential. When the family shareholders have absolute control, the family shareholders have the incentive and ability to supervise the company's operation. When dispersed ownership, since the dispersion of shareholders do not want to pay the cost of supervision, there are "free riders," the motivation of managers is difficult to form an effective supervision. Situation family shareholders with a number of major shareholders holding opposing managers are able to carry out effective supervision. Because these large shareholders with a certain number of shares held with a power of supervision, supervision of its income is greater than the cost of supervision. The survey of family business has accounted for $38.5 \%$ of the Board, has accounted for $41.7 \%$ of the shareholders 'meeting, the Supervisory Board has accounted for $16.7 \%$, with a workers' congress of $20.8 \%$, only $3.1 \%$ with a family of the Committee.

\subsection{Ownership Structure and acquisitions}

Merger is a very critical corporate governance mechanism. Merger will usually replace the former manager of the company, which is considered one of the most effective ways to control managers. Family shareholders in the ownership structure have absolute control, as the major shareholder of $\mathrm{M}$ family resisted mentality, resulting in costly acquisitions, mergers and acquisitions difficult to occur. The highly dispersed ownership for mergers and acquisitions are very favorable, so that the acquirer of the shares dispersed highly successful takeover bid. In relative controlling family shareholders, the situation is more complicated, the family shareholders to foreign buyers by raising the purchase price and other means to prevent the takeover is successful, but if the acquirer is the other major shareholder of the company, the acquisition of the difficulty is greatly reduced.

Will affect more different ownership structure on the role of family business management mechanisms circumstances summarized in Table 3, we can draw the following conclusions: Equity moderate concentration, relative controlling family shareholders, and ownership structure present in other large shareholders in general more favorable to corporate governance mechanisms play a role. Since these four governance mechanisms have a decisive impact on the company's business manager and led by acting on the principle of maximizing shareholder value, therefore, the class ownership structure than the other types of ownership structure, the company's performance optimal.

Table2. Effect of Different Ownership Structure of Family Enterprise Governance Mechanisms of action.

\begin{tabular}{cccc}
\hline Management & Highly Concentrate & Modest Concentrate & Highly separate \\
\hline Business Incentive & Good & Between & Bad \\
\hline Proxy Context & Bad & Good & Bad \\
\hline Oversight mechanisms & Between & Good & Bad \\
\hline Mergers and acquisitions & Bad & Between & Good \\
\hline
\end{tabular}

\section{Wenzhou Family Company Ownership Structure Optimization Trend Analysis}

\subsection{Family shareholders equity should be external}

Wenzhou family business can be divided into stages of development of entrepreneurship and rapid growth, stable period of development, with the development of family business ownership structure exhibit different characteristics. In the start-up stage, the enterprise funds from individual or family business owners, business owners I grasp business ownership and management, control, ownership is highly concentrated. This structure, while having internal agency low cost, but will hinder the enterprise to modern enterprise system, it is difficult to attract and retain talent; in the phase of rapid 
growth, companies need huge human resources and capital investment, shareholding structure to the outside of the development, under the supervision of outside investors more standardized operation of enterprises. Summarizes the family business practice in Europe and America and Southeast Asia, this may take several forms: through the issuance of shares to raise funds again, diluted stake held by controlling shareholder family; by way of a trust or a non-profit organization, to achieve equity diversification; the equity transfer to foreign operators, employees, the implementation of employee stock ownership plans.

\subsection{Separation of ownership and management, and establish the effective agency mechanism}

Family under highly concentrated ownership structure is difficult to establish a stable agency contract, which restricts the growth of family business motives, therefore, must be the ownership structure of family business to optimize the design. Sustainable development of family businesses need to separate ownership and management, the establishment of stable and effective agency mechanism, however, the key to the realization of the ownership structure optimization is to ensure a smooth transition from a family business in Wenzhou start-up phase to a phase of rapid growth and stable development stage. Further improve the independent director system, giving it greater powers, can participate in enterprise management; the introduction of professional manager system, the implementation of family business ownership and management rights effectively separated from the introduction of "ultimate owner" concept, based on the laws and regulations of the mechanism, all aspects of the company system building efforts, strengthen supervision, improve the information disclosure system.

\subsection{Entrepreneurs take the initiative to encourage transferring part of the shares listed on the family business}

Encourage entrepreneurs from transferring part of the initiative on institutional arrangements to encourage equity Wenzhou Family Firm, even the absolute control of the entrepreneur family is understandable, because only financial incentives for entrepreneurs, in order to promote familyoriented equity toward socialization. Entrepreneurs and their families in the entrepreneurial process to pay a heavy price, he assumed great risk, they start feeling allow "outsiders" to meddle in their own businesses. Therefore, entrepreneurs often prefer absolute holding company, in fact, is a non-rational choice. Motivation entrepreneurial business owners may be money, but the ultimate goal is to enable business entrepreneurs continues to grow, control only a means. Western show business history, any more than a hundred years, very few companies are in a family always controlled growth. Thus, after the completion of business, gradually give up absolute control over the enterprise does not violate entrepreneurs to achieve business development goals across generations. In contrast, shares of the family business by the dispersion of Wenzhou entrepreneurs transition to second-generation operators to provide greater range of options, the assignment of part of the shares in exchange for more room for development. By listing into public enterprises, further expand the scope of equity. Its ownership structure becomes the controlling shareholder, Dynamic Stability few large shareholders and the state of many small shareholders.

\subsection{Attract institutional investors}

Family business entrepreneurs to sell shares when investors should choose carefully, not just in order to get money and trouble to sell part of the shares should make investors' funds subject to the business development strategy. Business owners in the choice of investments should follow two criteria: first, investors are able to expand their business to provide substantive assistance; second, they only choose income does not seek control of institutional investors, choose a strategic alliance linking further improve the capital market for private enterprises diversified equity conditions are provided as shown, 
the family business is the goal of optimizing the equity diversified, dynamic ownership structure. Way to achieve this goal is to domestic and foreign stock exchanges. In addition, well-developed capital markets, but also to make the newly established family business out of the family of the financing model, from the starting point to a diversified ownership structure.

\subsection{Dynamic and diversified ownership structure}

Wide range of features to make enterprise agency contract between shareholders and managers is more stable and more efficient. Dynamic means having a stake in mobility, minority shareholders can transfer their shares at any time, to ensure the dynamic characteristics of risk-averse investors' needs of investors. As shown, the enterprise business development path of corporate equity 4.1 Changes in two lines, capital must be business development services. The only criterion is the return on capital institutional investors, as long as they can guarantee returns, they do not want to control specific business operations. They hold the right to vote is aimed at risk aversion rather than to control businesses. Currently, a small number of family enterprises in Wenzhou introduced foreign strategic investors, entrepreneurs do not still allow corporate CEOs, but also actively promote equity, even holding enterprises to expand overseas business, enabling enterprises to achieve greater development of entrepreneurs and investors.

\section{Conclusion}

Wenzhou family businesses play an important role in the current economy, and will also be the future economic development of the market cannot be ignored in Wenzhou enterprise groups. Core family business is the ownership and management rights of ownership, but from the point of view the situation of family business, family business ownership and management control in the hands of the general by blood, marriage, kinship as a link consisting of family members, with the accelerate the process of marketization and the rapid integration with the international requirements of family businesses unique to the family property system as the core shareholding structure severely restricted its development, equity structure optimization measures are necessary to achieve healthy growth of the family business.

\section{References}

[1] Jun Lu, Family Enterprise, How to use equity incentives? [J], Foreign Management, 2012(2).

[2] Zhou Tiancheng, The analysis of human resources management in Chinese family enterprises-Use Wenzhou as example [J], Jiangsu Commercial Forum, 2013(23):58-58.

[3] Xi Jing, Based on internal organization features Family Business Growth Obstacles and Solutions [J], Reform and strategy, 2010 (4).

[4] He Haihuai, Yi Miaoqing and Bao Aiping, Construction and Incentive of Wenzhou Family Business's Managers [J], Management experts, 2014(8).

[5] Jia Ying Asia, An Liren. Family business incentives Problems and Countermeasures - Based Discussion Wenzhou model [J], Tribune, 2011 (16).

[6]He Haihuai, Zhou Xiaomin, Wenzhou Family Enterprises Board Characteristics and efficiency improving strategy [J], China Industry Yearbook, 2014. (2). 